\title{
Interplay between IDO1 and iNOS in human retinal pigment epithelial cells
}

\author{
Katrin Spekker-Bosker ${ }^{1} \cdot$ Christoph-Martin Ufermann $^{1} \cdot$ Maike Oldenburg $^{1} \cdot$ Walter Däubener $^{1}$. \\ Silvia Kathrin Eller ${ }^{1}$ (1)
}

Received: 21 November 2018 / Accepted: 19 June 2019 / Published online: 2 July 2019

(c) The Author(s) 2019

\begin{abstract}
Human retinal pigment epithelial (hRPE) cells form a selectively permeable monolayer between the neural retina and the highly permeable choroidal vessels. Thus, hRPE cells bear important regulatory functions and are potential targets of pathogens in vivo. Endogenous bacterial endophthalmitis (EBE) is frequently caused by infections with the Gram-positive bacterium Staphylococcus aureus (S. aureus). Upon microbial infection, interferon gamma (IFN- $\gamma$ ), a major cytokine of the adaptive immune response, induces a broad spectrum of effector molecules, such as the tryptophan-degrading enzyme indoleamine 2,3-dioxygenase-1 (IDO1). We stimulated human RPE (hRPE) cells in vitro with proinflammatory cytokines and analyzed the expression levels and enzymatic activities of IDO1 and inducible nitric oxide synthase (iNOS), another antimicrobial effector molecule. The antimicrobial capacity was analyzed in infection experiments using S. aureus and Toxoplasma gondii (T. gondii). Our aim was to characterize the particular importance of IDO1 and iNOS during EBE. We found that an IFN- $\gamma$ stimulation of hPRE cells induced the expression of IDO1, which inhibited the growth of T. gondii and $S$. aureus. A co-stimulation with IFN- $\gamma$, interleukin-1 beta, and tumor necrosis factor alpha induced a strong expression of iNOS. The iNOS-derived nitric oxide production was dependent on cell-culture conditions; however, it could not cause antimicrobial effects. iNOS did not act synergistically with IDO1. Instead, iNOS activity inhibited IDO1-mediated tryptophan degradation and bacteriostasis. This effect was reversible by the addition of the iNOS inhibitor $N^{\mathrm{G}}$-monomethyl-L-arginine. In conclusion, iNOS mediates anti-inflammatory effects in hRPE cells stimulated with high amounts of IFN- $\gamma$ together with tumor necrosis factor alpha and Interleukin-1 beta and prevents potential IDO1-dependent tissue damage.
\end{abstract}

Keywords Endogenous bacterial endophthalmitis · Indoleamine 2,3-dioxygenase-1 $\cdot$ IDO1 $~$ Inducible nitric oxide synthase $\cdot$ iNOS $\cdot$ Retinal pigment epithelial cells $\cdot$ Staphylococcus aureus $\cdot$ Toxoplasma gondii

Edited by: Jonathan Jantsch.

Katrin Spekker-Bosker and Christoph-Martin Ufermann contributed equally to this work.

Electronic supplementary material The online version of this article (https://doi.org/10.1007/s00430-019-00627-4) contains supplementary material, which is available to authorized users.

Silvia Kathrin Eller

silvia.eller@uni-duesseldorf.de

1 Institute of Medical Microbiology and Hospital Hygiene, Heinrich-Heine-University Düsseldorf, Universitätsstr. 1, Bldg. 22.21, 40225 Düsseldorf, Germany

\section{Introduction}

Endophthalmitis and infectious retinitis are sight-threatening diseases, which are characterized by infections and subsequent proinflammatory immune responses. The strict control of proinflammatory responses is required to minimize tissue damage [1, 2]. The immune response against pathogens is dependent on the production of interferon gamma (IFN- $\gamma$ ), which is mainly derived from NK cells and T cells [3]. However, the eye is an immune-privileged organ and the vulnerable neurosensory cells have to be protected from damage by proinflammatory effector cells. Retinal pigment epithelial (RPE) cells are able to regulate $\mathrm{T}$ cell responses in the eye $[2,4]$ and are well known effector cells against Toxoplasma gondii (T. gondii) [5, 6] and cytomegalovirus (CMV) [7, 8]. 
Both cause severe diseases in immunocompromised patients, for example, retinitis, pneumonia, and encephalitis.

An exogenous endophthalmitis frequently occurs after penetrating ocular traumata and is a serious complication after eye surgery. In this case, environmental pathogens such as bacteria or fungi invade the eye and cause an infection. Despite the fact that exogenous endophthalmitis is a harmful infection, it is usually no source of bacteremia [1]. Postsurgery infections mostly occur due to coagulase negative staphylococci and propionibacteria, while the majority of post-traumatic exogenous endophthalmitis cases are caused by Bacillus cereus [1].

In contrast to an exogenous endophthalmitis, endogenous bacterial endophthalmitis (EBE) is a rare infection, but is often associated with poor visual outcome and can be life threatening. EBE is usually a complication of a systemic infection. During a systemic infection, characterized by sepsis (positive blood culture in 58\%) and fever (in 74\%), bacteria are distributed via the blood stream throughout the body. Bacteria that reach the eye can cross the blood-retinal barrier and establish EBE. Staphylococcus aureus ( $S$. aureus), streptococci, and enterobacteria are the most frequently found causative agents of EBE [9, 10]. Infection of indwelling catheters or prosthetic devices with $S$. aureus is associated with bacterial endocarditis and is the major cause of EBE in Europe and the United States of America. Diabetes mellitus and immunosuppression are additional risk factors for a systemic bacterial infection and thus EBE $[9,10]$.

Pathogens causing EBE have to pass the blood-ocular barrier, namely, the blood-aqueous barrier and the blood-retinal barrier. The blood-aqueous barrier consists of endothelial cells of the retina capillary vessels and is in direct contact with pericapillary glial cells. The outer blood-retinal barrier consists of the RPE cells and the underlying Bruch's membrane and separates the neuronal retina from the fenestrated choriocapillaris. The barrier function of RPE cells is accomplished by tight junctions. The flow of nutrients and macromolecules from the blood to the retina is thereby regulated and the entry of pathogens and immune cells to the eye is restricted [11]. In addition, RPE cells are immune competent. They produce several cytokines including interleukin-1 (IL-1) and tumor necrosis factor alpha (TNF $\alpha$ ), can activate $\mathrm{T}$ cells and are able to restrict the growth of pathogens [12]. The antimicrobial capacity of the RPE has been analyzed by several groups. For example, RPE cells are susceptible to different viruses such as Herpes simplex virus, cytomegalovirus, adenovirus types 1 and 7, and measles virus [13]. Furthermore, IFN- $\gamma$ activated RPE cells can restrict the growth of $T$. gondii and CMV, which are both capable to induce retinitis. In general, indoleamine 2,3-dioxygenase-1 (IDO1) and inducible nitric oxide synthase (iNOS) were identified as prominent IFN- $\gamma$ induced effector mechanisms against CMV [7].
iNOS can be expressed in retinal pigment epithelial cells from mice and rats $[14,15]$. The observation that iNOSdeficient mice have an increased CMV load in the retina after CMV infection is a hint for a functional involvement of iNOS in the microbial defense [16]. Human RPE (hRPE) cells express iNOS; however, iNOS induction by cytokines or by environmental factors differs between species [17, 18]. In addition to its role in antimicrobial response, iNOS has also been found to be involved in the development of ischemic retinopathies [19], age-related macular degeneration [20], chronic glaucoma [21], and diabetic retinopathy [22]. In contrast to the antiviral effects mediated by iNOS in murine cells, Bodagi et al. found that iNOS is not important in the defense of hRPE cells against CMV [7]. Instead, IFN- $\gamma$ induced IDO1 served as an antiviral defense mechanism in native hRPE cells. In accordance Nagineni et al. described, the IFN- $\gamma$ stimulation of primary hRPE cells induced IDO1, which inhibited the growth of $T$. gondii [6].

Thus, IDO1- and iNOS-mediated effects against $T$. gondii and CMV have been studied intensively. However, relatively few information is available regarding the RPE cell-mediated antimicrobial defense against bacteria, especially with the focus on $S$. aureus causing EBE. Healthy and diabetic C57BL/6 mice develop EBE after intravenous infection with $S$. aureus [23]. An in vitro infection with $S$. aureus results in disruption of the tight junctions of hRPE cells [10]. Furthermore, hRPE cells can phagocytose $S$. aureus and present staphylococcal superantigens to $T$ cells $[24,25]$. The defense mechanisms against $S$. aureus mediated by the RPE are unclear; however, respiratory burst is likely not involved [24]. Therefore, we aimed to analyze the role of iNOS and IDO1 in the defense against $S$. aureus in hRPE cells.

\section{Materials and methods}

\section{Cells, media, and reagents}

Human retinal pigment epithelial (hRPE) cells (ARPE-19, ATCC, Wesel, Germany), as well as human foreskin fibroblasts (HFF) (ATCC, Wesel, Germany) and human glioblastoma cells (86HG39) were cultured in Iscove's modified Dulbecco's medium (IMDM) (Gibco, Grand Island, USA), supplemented with 5\% heat-inactivated fetal calf serum (FCS). Cells were cultured in culture flasks (Costar, Cambridge, USA) in a humidified incubator $\left(37^{\circ} \mathrm{C}\right.$, $5 \% \mathrm{CO}_{2}$ ). Cells were passaged weekly in 1:10 ratios using trypsin/EDTA (Gibco, Grand Island, USA). Hypoxia growth experiments were carried out using a HERAcell $150 \mathrm{I} \mathrm{CO}_{2}$ incubator (Thermo Fisher Scientific, Carlsbad, USA) or the Anoxomat ${ }^{\mathrm{TM}}$ system (Mart Microbiology B. V., Drachten, Netherlands) with $1-10 \% \mathrm{O}_{2}$ and $5 \% \mathrm{CO}_{2}$. Mycoplasma 
contamination was regularly excluded by culture methods and PCR.

A tryptophan-auxotrophic Staphylococcus aureus isolate was used. This $S$. aureus isolate was obtained from a routine diagnostic specimen [26]. S. aureus was grown on brain heart infusion agar containing 5\% sheep blood (Difco, Hamburg, Germany) at $37{ }^{\circ} \mathrm{C}$ in $5 \% \mathrm{CO}_{2}$-enriched atmosphere overnight.

Toxoplasma gondii tachyzoites (ME49 strain, ATCC, Wesel, Germany) were maintained in HFF in IMDM containing 5\% FCS. Extracellular tachyzoites were harvested from culture supernatants by centrifugation, resuspended in tryptophan free RPMI, counted and used as indicated for infection experiments.

\section{Stimulation of hRPE cells}

For infection experiments as well as for the determination of IDO1 and iNOS activity, hRPE cells were seeded in 96 -well plates $\left(3 \times 10^{4}\right.$ cells per well) or 24 -well plates $\left(3 \times 10^{4}, 1 \times 10^{5}, 3 \times 10^{5}\right.$ or $5 \times 10^{5}$ cells per well $)$ and stimulated with recombinant human IFN- $\gamma(0-2000 \mathrm{U} / \mathrm{ml})(\mathrm{R} \& \mathrm{D}$ Systems, Minneapolis, USA) and/or recombinant human IL-1 $\beta$ (100 U/ml) (R\&D Systems, Minneapolis, USA) and/or recombinant human TNF $\alpha(100 \mathrm{U} / \mathrm{ml})(\mathrm{R} \& \mathrm{D}$ systems, Minneapolis, USA) for $72 \mathrm{~h}$ in a humidified incubator $\left(37^{\circ} \mathrm{C}, 5 \%\right.$ $\mathrm{CO}_{2}$ ). In the iNOS activity kinetic experiments, supernatants were harvested after $0,24,48,72$, or $96 \mathrm{~h}$ and analyzed with the nitric oxide assay. Subsequent infection experiments as well as IDO1 and iNOS activity measurements were performed with pre-stimulated cells.

In some experimental groups, the NOS inhibitor $N^{\mathrm{G}}$ monomethyl-L-arginine ( ${ }^{\mathrm{G}} \mathrm{MMA}$ ) (Merck, Darmstadt, Germany) $(100 \mu \mathrm{g} / \mathrm{ml})$ or the competitive IDO inhibitor 1-L-methyL-tryptophan (1-MT) (Sigma-Aldrich, St. Louis, USA) $(1.5 \mathrm{mM})$ were used.

\section{Kynurenine assay}

The enzymatic activity of IDO1 directly correlates with the concentration of kynurenine in supernatants of tissue culture cells, and therefore, the measurement of kynurenine can be used to determine IDO1 activity [27]. The kynurenine content of supernatants from unstimulated or stimulated cells was analyzed using 4-(dimethylamino) benzaldehyde (Ehrlich's reagent) as described before [27].

\section{Nitric oxide assay}

Nitrite accumulation in the supernatant of cultured cells was used as an indicator of nitric oxide production and was determined by the Griess reaction [28]. In brief, $100 \mu \mathrm{l}$ cellculture supernatant of pre-stimulated hRPE cells (for $72 \mathrm{~h}$ ) was mixed with $100 \mu \mathrm{l}$ Griess Reagent (0.1\% $N$-(1-naphthyl) ethylenediamine in purified water and $2.5 \%$ sulfonamide in $15 \%$ hydrochloric acid in a 1:1 ratio; Merck, Darmstadt, Germany). After an incubation time of $15 \mathrm{~min}$, the absorbance was measured at $540 \mathrm{~nm}$ (TECAN Sunrise microplate reader, Crailsheim, Germany). The amount of nitrite accumulation was determined using a calibration curve of graded concentrations of sodium nitrite.

\section{Determination of bacterial growth}

A 24-h-old $S$. aureus colony was picked, resuspended in PBS (Gibco, Grand Island, USA), and serial diluted. After prestimulation with cytokines for $72 \mathrm{~h}$, hRPE cells (cultured in 96 flat-bottom culture plates) were infected with $10 \mu \mathrm{l}$ of the bacterial dilution containing 10-100 colony forming units (cfu). Alternatively, conditioned medium from stimulated hRPE cultures (harvested $72 \mathrm{~h}$ after cytokine stimulation) was inoculated with the same amount of bacteria. Infected cultures were incubated in a humidified incubator $\left(37^{\circ} \mathrm{C}, 5 \%\right.$
Table 1 Real-time PCR primers for the detection of human betaactin, nitric oxide synthase, and indoleamine 2,3-dioxygenase-1 transcripts

\begin{tabular}{lllllll}
\hline Gene of interest & Gene ID & Probe & Sequence $\left[5^{\prime} \rightarrow 3^{\prime}\right]$ & Length \\
\hline$\beta$-Actin & ENSG00000075624 & $\# 64$ & fw & ccaaccgcgagaagatga & 18 \\
& & & rv & ccagaggcgtacagggatag & 20 \\
iNOS (inducible, NOS2) & ENSG00000007171 & $\# 16$ & fw & tcttcctggtttgactgtcctta & 23 \\
& & & rv & gctcagatgttcttcactgtgg & 22 \\
eNOS (endothelial, NOS3) & ENSG00000164867 & $\# 67$ & fw & gactgaaggctggcatctg & 19 \\
& & & rv & ccatgttactgtgcgtccac & 20 \\
nNOS (neuronal, NOS1) & ENSG00000089250 & $\# 39$ & fw & tgggagactgaggtggttct & 20 \\
& & & rv & gtactcagtgcatccegtttc & 21 \\
IDO1 & ENSG00000131203 & $\# 9$ & fw & cgccttgcacgtctagttct & 20 \\
& & & rv & ttggcagtaaggaacagcaat & 21 \\
IDO2 & ENSG00000188676 & $\# 4$ & fw & ttcctcaccatgggttatgtc & 21 \\
& & & rv & gaagggcaagattcttgg & 19 \\
\hline
\end{tabular}


a
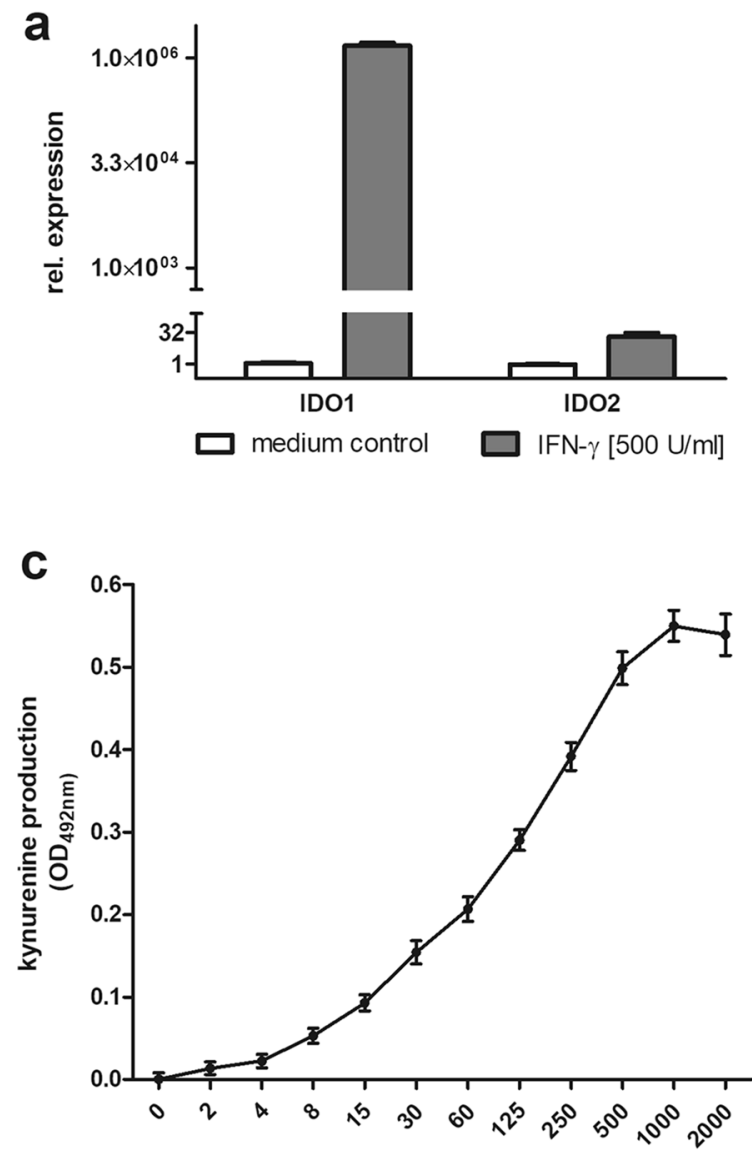

IFN- $\gamma[\mathrm{U} / \mathrm{ml}]$

e

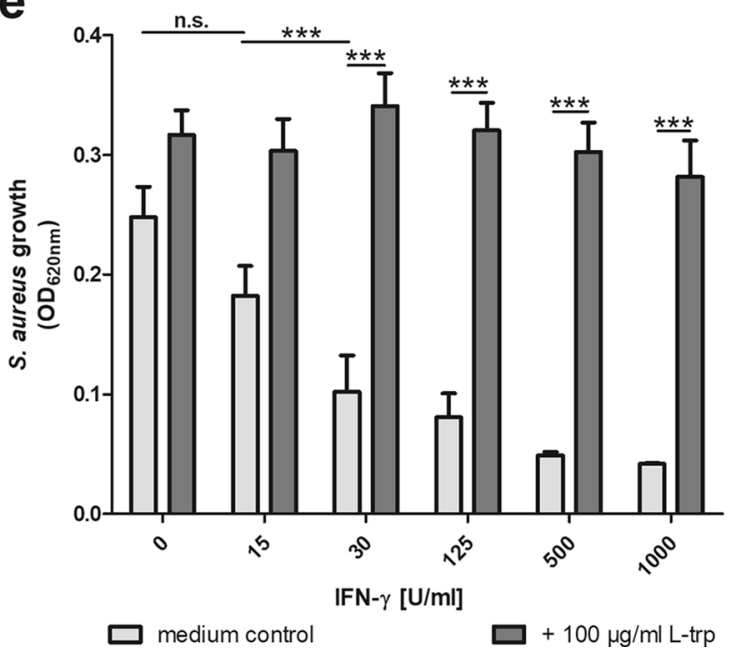

$\mathrm{CO}_{2}$ ) for $16 \mathrm{~h}$. Bacterial growth was monitored by measuring the optical density of resuspended cultures at $620 \mathrm{~nm}$ (TECAN Sunrise microplate reader, Crailsheim, Germany) [26]. b

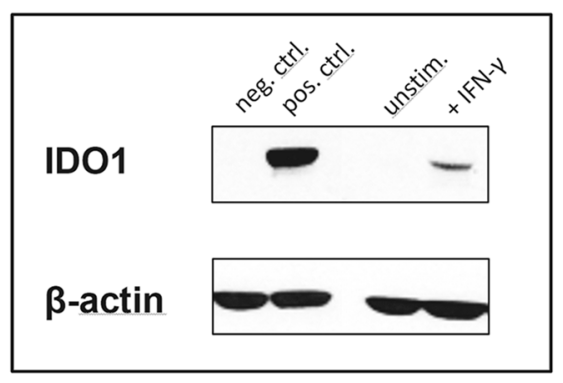

d

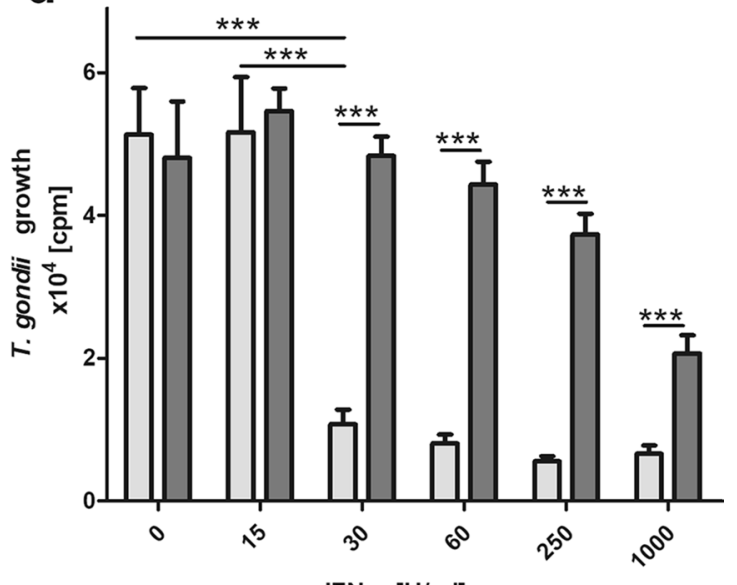

$\mathrm{IFN}-\gamma[\mathrm{U} / \mathrm{ml}]$

$\square$ medium control $\square+100 \mu \mathrm{g} / \mathrm{ml}$ L-trp

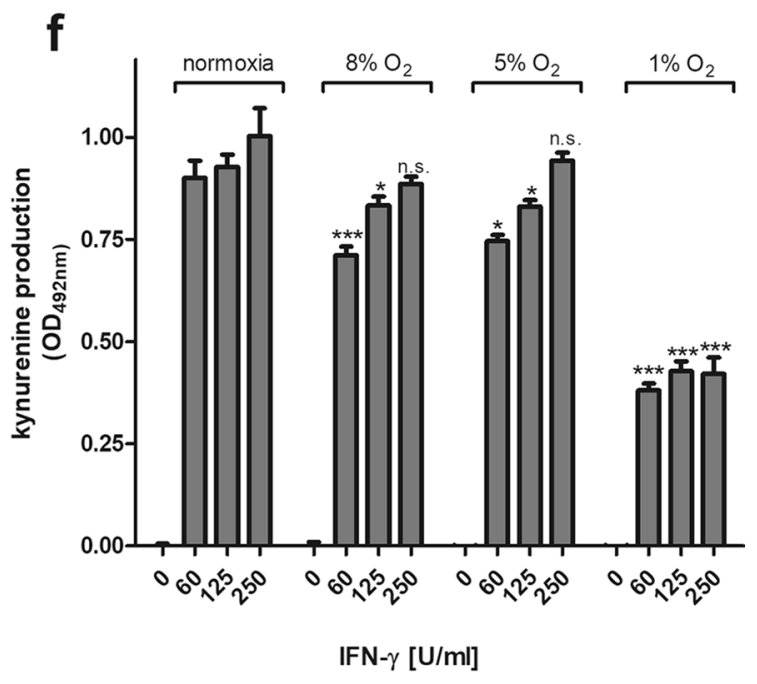

Determination of parasite growth

After pre-stimulation for $72 \mathrm{~h}$, hRPE cells were infected with $2 \times 10^{4} T$. gondii tachyzoites per well. $T$. gondii growth was determined by the ${ }^{3} \mathrm{H}$-uracil incorporation method as described before [26, 29]. In brief, ${ }^{3} \mathrm{H}$-uracil $(0.33 \mu \mathrm{Ci}$ per 
४Fig. 1 Activity of indoleamine 2,3-dioxygenase (IDO) in human retinal pigment epithelial (hRPE) cells. a Relative expression of IDO1 and IDO2 in unstimulated (medium control) or IFN- $\gamma(500 \mathrm{U} / \mathrm{ml}$ for $24 \mathrm{~h}$ ) stimulated hRPE cells, detected by real-time PCR. b Exemplary western blot analysis showing IDO1 negative and positive control (human glioblastoma lysates) and IDO1 and $\beta$-actin protein in unstimulated and IFN- $\gamma(500 \mathrm{U} / \mathrm{ml}$ for $24 \mathrm{~h})$ stimulated hRPE cells. c $3 \times 10^{4}$ hRPE cells were stimulated in 96-well plates with indicated concentrations of human IFN- $\gamma(0-2000 \mathrm{U} / \mathrm{ml})$ in the presence of L-tryptophan (L-trp; $100 \mu \mathrm{g} / \mathrm{ml}$ ). After $72 \mathrm{~h}$, the cell-culture supernatants were harvested and the kynurenine content was determined by the use of Ehrlich's reagent. $(\mathrm{d}+\mathrm{e}) 3 \times 10^{4} \mathrm{hRPE}$ cells pre-stimulated with IFN- $\gamma$ for $72 \mathrm{~h}$. d Pre-stimulated hRPE cell cultures were infected with Toxoplasma gondii $\left(1 \times 10^{5} \mathrm{ME} 49\right.$ tachyzoites/well $)$ or (e) Staphylococcus aureus (10-100 cfu/well) without additional L-tryptophan (medium control) or with L-tryptophan $(100 \mu \mathrm{g} / \mathrm{ml})$ supplementation. Parasite growth was determined via the ${ }^{3} \mathrm{H}$-Uracil method and the bacterial growth was detected by the optical density at $620 \mathrm{~nm}\left(\mathrm{OD}_{620 \mathrm{~nm}}\right)$. f $3 \times 10^{4} \mathrm{hRPE}$ cells were stimulated with indicated IFN- $\gamma$ concentrations under atmospheric oxygen concentration (normoxic) or hypoxic $\left(8 \% \mathrm{O}_{2}, 5 \% \mathrm{O}_{2}\right.$, or $\left.1 \% \mathrm{O}_{2}\right)$ conditions in the presence of L-tryptophan $(100 \mu \mathrm{g} / \mathrm{ml})$. Ehrlich's reagent was used to measure the kynurenine content. Data are given as mean \pm SEM of two (a), one (b), three (c), five (d), four (e), or three (f) experiments, each performed in triplicate. Significant differences to the unstimulated or normoxic group are indicated with asterisks (n.s. not significant, $* p \leq 0.05, * * p \leq 0.001, * * * p \leq 0.0001)$. The unpaired, two-tailed student's $t$ test was used

well) was added $48 \mathrm{~h}$ postinfection. Cultivation was stopped after additional $24 \mathrm{~h}$ by freezing. Parasite growth was determined by measuring incorporated ${ }^{3} \mathrm{H}$-uracil using liquid scintillation spectrometry (1205 Betaplate, PerkinElmer, Jugesheim, Germany).

\section{Real-time PCR}

hRPE cells were seeded into 6-well plates $\left(10^{6} \mathrm{hRPE}\right.$ cells per well) and stimulated with combinations of the respective cytokines IFN- $\gamma(500 \mathrm{U} / \mathrm{ml}), \mathrm{IL} 1-\beta(100 \mathrm{U} / \mathrm{ml}), \mathrm{TNF} \alpha$ $(100 \mathrm{U} / \mathrm{ml})$, and $\mathrm{N}^{\mathrm{G}} \mathrm{MMA}(100 \mu \mathrm{g} / \mathrm{ml})$ or left untreated for $24 \mathrm{~h}$ in a humidified incubator at $37{ }^{\circ} \mathrm{C}$ and $5 \% \mathrm{CO}_{2}$ [8]. For sample collection, the medium was aspirated and cells were detached in PBS by scraping. Total RNA was extracted according to the TRI Reagent protocol (Merck, Darmstadt, Germany). RNA was dissolved in UltraPure ${ }^{\mathrm{TM}}$ distilled water (Thermo Fisher Scientific, Carlsbad, USA) and RNA concentration was determined via NanoDrop (Thermo Fisher Scientific, Carlsbad, USA). Reverse transcription of $2 \mu \mathrm{g}$ total RNA to cDNA was performed with M-MLV reverse transcriptase and oligo(dT) ${ }_{12-18}$ primers (Thermo Fisher Scientific, Carlsbad, USA). PCR primers to amplify the genes of interest are listed in Table 1. Real-time PCR was performed with the Takyon NoRox Probe MasterMix dTTP (Eurogentec, Lüttich, Belgium) on a Bio-Rad CFX96 Touch Real-Time PCR Detection system (Bio-Rad Laboratories, Hercules, USA). All reactions, including non-template contamination controls, were performed in duplicates. Each well of a multiplate 96-well PCR plate contained $5 \mu \mathrm{l}$ cDNA template, $12.5 \mu \mathrm{l}$ Takyon NoRox Probe Master Mix dTTP, $0.3 \mu \mathrm{l}$ primer $(20 \mu \mathrm{M}$ each $), 0.5 \mu \mathrm{l}$ probe $(10 \mu \mathrm{M})$, and $6.4 \mu \mathrm{l}$ $\mathrm{H}_{2} \mathrm{O}$ for a total reaction volume of $25 \mu \mathrm{l}$ (Table 1). The PCR conditions were $7 \mathrm{~min}$ at $95^{\circ} \mathrm{C}$ and 40 cycles of each $94{ }^{\circ} \mathrm{C}$ for $20 \mathrm{~s}$ and $60^{\circ} \mathrm{C}$ for $1 \mathrm{~min}$.

\section{Western blot analysis}

$6,75 \times 10^{6} \mathrm{hRPE}$ cells were incubated in cell-culture flasks (Costar, Cambridge, USA) in the absence or presence of IFN- $\gamma(500 \mathrm{U} / \mathrm{ml}), \mathrm{IL}-1 \beta(100 \mathrm{U} / \mathrm{ml})$, and TNF $\alpha(100 \mathrm{U} /$ $\mathrm{ml})$ for $24 \mathrm{~h}$. The supernatant was discarded and the cell monolayer was washed three times with cold PBS. The cells were detached by scraping in $200 \mu \mathrm{l}$ PBS containing a protease inhibitor cocktail (Roche Diagnostics, Mannheim, Germany). Thereafter, the cells were lysed by three freeze/thaw cycles, centrifuged and the cell extract was stored at $-80^{\circ} \mathrm{C}$. IFN- $\gamma(500 \mathrm{U} / \mathrm{ml})$ stimulated human glioblastoma cell extracts served as a control. The protein amount was determined via Bradford assay (Bio-Rad Laboratories, Hercules, USA). Electrophoretic separation of proteins ( $30 \mu \mathrm{g}$ protein per lane) was done with $10 \%$ NuPAGE Novex Bis-Tris Mini gels in the appropriate electrophoresis system (Thermo Fisher Scientific, Carlsbad, USA). Separated proteins were semi-dry blotted on nitrocellulose membranes (CarboGlas, Schleicher \& Schüll, Dassel, Germany). After blocking the membranes in 5\% (w/v) skim milk powder in PBS for $1 \mathrm{~h}$ at room temperature, the nitrocellulose membranes were incubated for $1.5 \mathrm{~h}$ at room temperature in the respective primary antibodies diluted in $0.5 \%(\mathrm{w} / \mathrm{v})$ skim milk powder in TBS: anti- $\beta$-actin antibody (1:5000, Sigma, St. Louis, USA) or anti-human-IDO1 antibody (1:500, Merck, Darmstadt, Germany). Thereafter, the membranes were washed with PBS for three times $(5 \mathrm{~min})$ and incubated for $2 \mathrm{~h}$ at room temperature with goat anti-mouse HRP-conjugated (IDO1) or goat anti-rabbit HRP-conjugated (ß-actin) IgG (1:10,000-70,000, Jackson Immuno Research Laboratories, Dianova, Hamburg, Germany), diluted in $0.5 \%$ (w/v) skim milk powder in PBS. After additional washes with PBS, bands were detected by enhanced chemiluminescence (Amersham Pharmacia Biotech, Freiburg, Germany).

\section{Statistical analysis}

All experiments were performed in duplicates or triplicates (as indicated in the figure legends) and data are given as mean \pm SEM of a minimum of three independent experiments. For statistical analysis the unpaired two-tailed students $t$ test was used and significant differences were marked with asterisks $(* p<0.05 ; * * p<0.001 ; * * * p<0.0001)$. The statistical analysis was performed with GraphPad Prism software. 
a

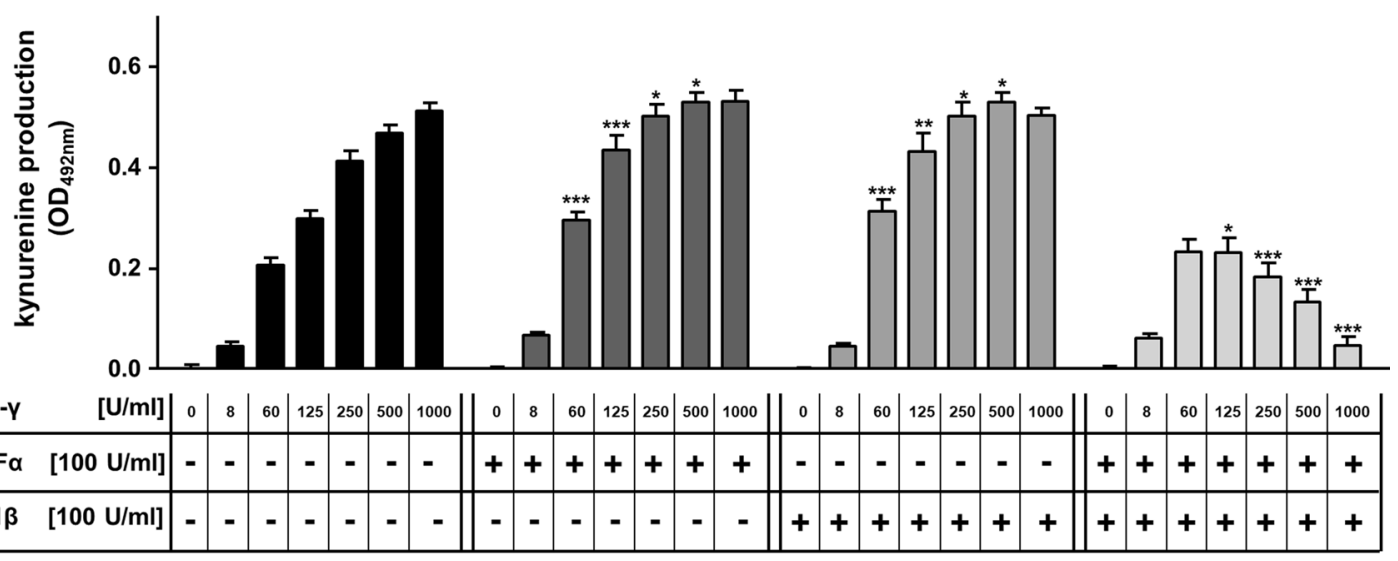

b

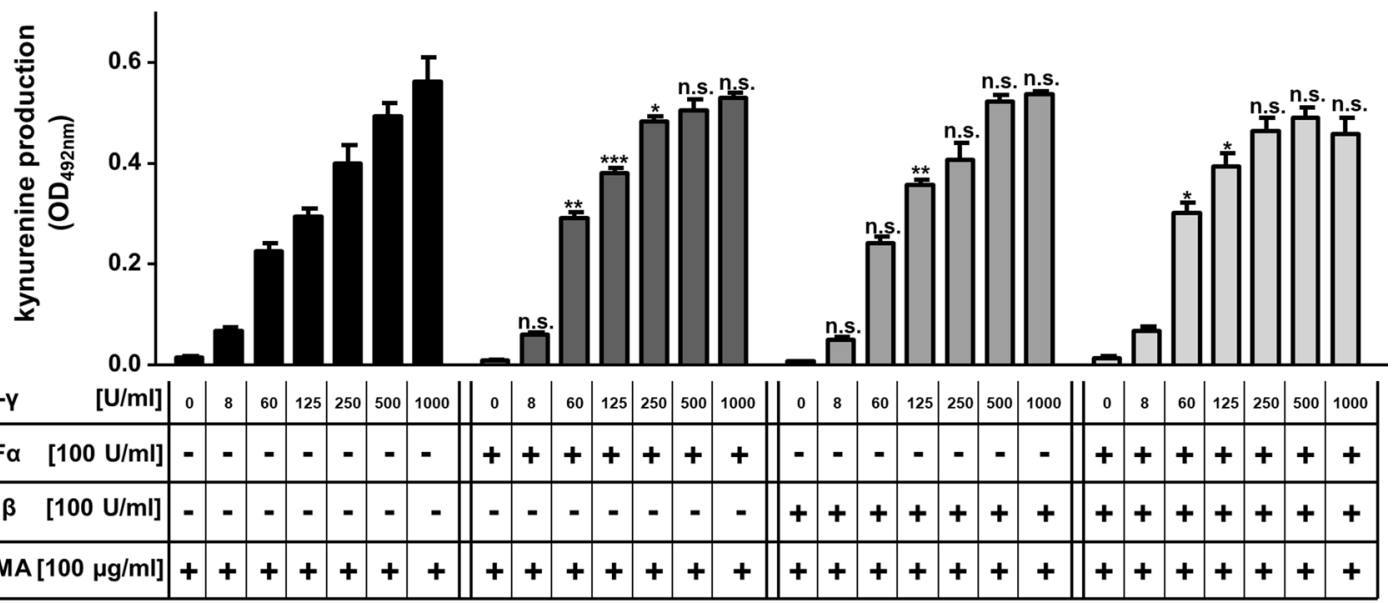

C

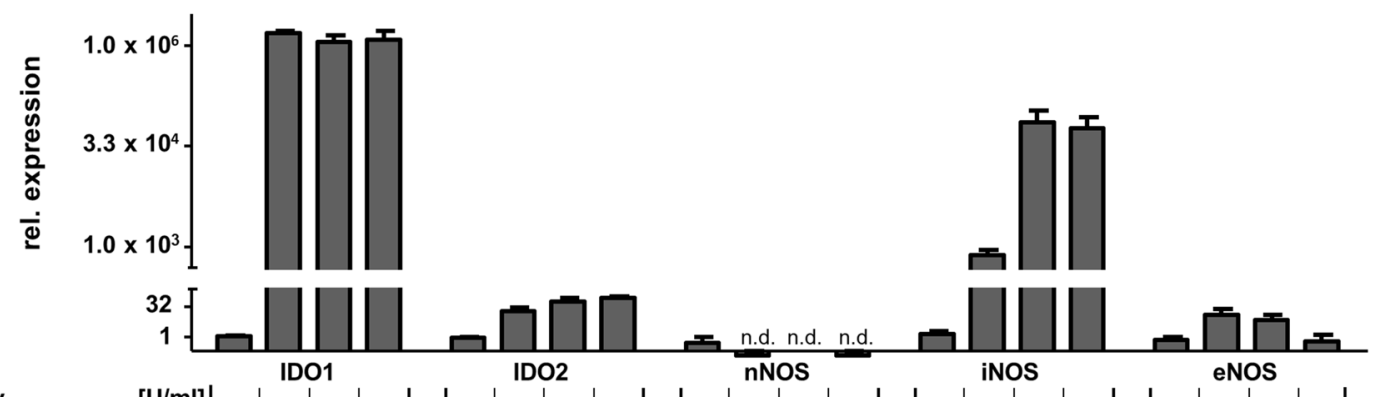

\begin{tabular}{|c|c|c|c|c|c|c|c|c|c|c|c|c|c|c|c|c|c|c|c|c|c|}
\hline IFN-Y & {$[\mathrm{U} / \mathrm{ml}]$} & $=$ & 500 & 500 & 500 & - & 500 & 500 & 500 & - & 500 & $500 \mid$ & 500 & - & 500 & 500 & 500 & - & 500 & 500 & $500 \mid$ \\
\hline $\mathrm{NFa}$ & {$[100 \mathrm{U} / \mathrm{ml}]$} & - & - & + & + & - & - & + & + & $=$ & - & + & + & $=$ & - & + & + & - & - & + & + \\
\hline GMMA & {$[100 \mu \mathrm{g} / \mathrm{ml}]$} & - & - & - & + & - & - & - & + & - & - & - & + & - & - & - & + & - & - & - & + \\
\hline
\end{tabular}

Fig. 2 Influence of the inducible NO synthase (iNOS) on indoleamine 2,3-dioxygenase-1 (IDO1) activity in human retinal pigment epithelial (hRPE) cells. a $3 \times 10^{4}$ hRPE cells were stimulated in 96-well plates with indicated concentrations of human IFN- $\gamma(0-1000 \mathrm{U} / \mathrm{ml})$ in the presence of $100 \mu \mathrm{g} / \mathrm{ml}$ L-tryptophan and in the absence $(-)$ or presence $(+)$ of IL-1 $\beta(100 \mathrm{U} / \mathrm{ml})$ and TNF $\alpha(100 \mathrm{U} / \mathrm{ml})$. After $72 \mathrm{~h}$, the cell-culture supernatants were harvested and the kynurenine content was determined by the use of Ehrlich's reagent. b Same experi- mental setting with additional supplementation of the iNOS inhibitor $\mathrm{N}^{\mathrm{G}} \mathrm{MMA}(100 \mu \mathrm{g} / \mathrm{ml})$. c Relative expression of IDO1, IDO2, nNOS, iNOS, and eNOS detected by real-time PCR $24 \mathrm{~h}$ after stimulation. Data are given as mean \pm SEM of five $(\mathbf{a}, \mathbf{b})$ or two (c) experiments, each performed in triplicate. Significant differences to the unstimulated group were marked with asterisks (n.s. not significant, n.d. not detected, $* p \leq 0.05, * * p \leq 0.001, * * * p \leq 0.0001)$. The unpaired, twotailed student's $t$ test was used 


\section{Results}

\section{Indoleamine 2,3-dioxygenase-1 mediates antimicrobial functions in hRPE cells}

Our aim was to analyze antibacterial effectors in IDO-positive human retinal pigment epithelial (hRPE) cells, since IDO-mediated antibacterial effects have been described in human cells before [6,7]. Hence, we stimulated hRPE cells with IFN $-\gamma$ and found a strong expression of IDO1 mRNA $\left(10^{6}\right.$ fold higher than in unstimulated cells), whereas IDO2 mRNA was only marginally induced (32-fold) and thus might be neglectable (Fig. 1a, b).

IDO1 activity was assured by the measurement of kynurenine, the product of IDO1-mediated tryptophan degradation. For this purpose, hRPE cells were stimulated in a tryptophan-enriched cell-culture medium with different amounts of IFN- $\gamma$ for $72 \mathrm{~h}$ and the accumulated amount of kynurenine in the cell-culture supernatants was quantified by the use of Ehrlich's reagent. IDO1 activity was clearly dependent on the IFN- $\gamma$ dose used (Fig. 1c) and even $4 \mathrm{U} / \mathrm{ml} \mathrm{IFN- \gamma}$ were sufficient to induce a significant increase $(p>0.001)$ of kynurenine production. To further prove that IDO1 is the responsible antimicrobial effector molecule in stimulated hRPE cells, we performed additional experiments using the IDO1-specific inhibitor 1-methyl-L-tryptophan (1-MT). These data are included in the electronic supplementary material (ESM 1). 1-MT treatment of IFN- $\gamma$ stimulated hRPE cells inhibits IDO1 activity, as detected by kynurenine measurement (ESM 1a).

Next, we tested whether IDO1 could sufficiently degrade the conventional tryptophan amounts in the IMDM cellculture medium to inhibit the growth of pathogens. It has been shown before that IDO1 inhibits RH (type I) strain Toxoplasma gondii in hRPE cells [6]. Herein, we tested the efficiency of IDO1 activity against ME49 parasites, since type II strains are the most frequently found $T$. gondii strains in patients [30]. IFN- $\gamma$ pre-stimulated hRPE cells were infected with $T$. gondii and the intracellular growth was quantified after 3 days using the ${ }^{3} \mathrm{H}$-uracil method. T. gondii tachyzoites grew in unstimulated hRPE cells, but the presence of $30 \mathrm{U} / \mathrm{ml} \mathrm{IFN- \gamma}$ was sufficient to inhibit the parasite growth significantly (Fig. 1d). This antiparasitic effect was due to IDO1-mediated tryptophan degradation, since the supplementation of L-tryptophan at the timepoint of infection abrogated the effect (Fig. 1d). Interestingly, there was no full recovery of $T$. gondii growth in hRPE cells that were pre-treated with high doses of IFN- $\gamma$.

Since stimulated hRPE cells displayed an effective IDO1 activity, we then checked their ability to inhibit $S$. aureus growth as well. We used a patient-derived tryptophan auxotroph $S$. aureus strain to infect hRPE cells that were pre-stimulated with different amounts of IFN- $\gamma$ for $72 \mathrm{~h}$. The bacterial growth was analyzed $16 \mathrm{~h}$ postinfection by measuring the optical density. Bacteria grew in the presence of unstimulated cells. S. aureus growth was significantly inhibited by hRPE cells pre-stimulated with $30 \mathrm{U} / \mathrm{ml} \mathrm{IFN}-\gamma$ or more ( $p<0.0001$, Fig. 1e). The antibacterial effect could be ascribed to IDO1-mediated tryptophan degradation, since the supplementation of L-tryptophan at the timepoint of infection allowed an unrestricted bacterial growth (Fig. 1e). Furthermore, the IDO-specific inhibitor 1-MT abrogated the antibacterial effect as well (ESM 1b).

hRPE cells are localized in a region of the eye with a physiologic oxygen concentration of approx. $8 \% \mathrm{O}_{2}$ [35]. Since IDO1 activity is dependent on the presence of oxygen, we analyzed the kynurenine production in hRPE cells under different oxygen conditions. hRPE cells were incubated under normoxia, $8 \% \mathrm{O}_{2}, 5 \% \mathrm{O}_{2}$, or $1 \% \mathrm{O}_{2}$ in the presence of different IFN- $\gamma$ concentrations. IDO1 activity was again measured on the basis of the kynurenine content in the cell-culture supernatants. At $8 \% \mathrm{O}_{2}$, IDO1 activity in hRPE cells is slightly reduced at lower IFN- $\gamma$ concentrations (60 and $125 \mathrm{U} / \mathrm{ml}$ ). However, there was no significant impact on IDO1 activity when the hRPE cells were treated with higher amounts of IFN- $\gamma(250 \mathrm{U} / \mathrm{ml})$ (Fig. 1f). In contrast to this, the hypoxic environment of only $1 \% \mathrm{O}_{2}$ resulted in a significant decrease of IDO1 activity, even in the presence of higher IFN- $\gamma$ concentrations (Fig. 1f). In addition, the presence of $1 \% \mathrm{O}_{2}$ results in a strong inhibition of IFN- $\gamma$ induced antibacterial effect, while in the presence of $8 \% \mathrm{O}_{2}$, a more or less complete antibacterial effect of IFN- $\gamma$ was detected (ESM 1c).

\section{Inducible NO synthase is induced in hRPE cells by cytokine co-stimulation}

The antiparasitic effect against RH strain $T$. gondii tachyzoites is not only provoked by IFN- $\gamma$, but also by other proinflammatory cytokines and synergistic effects have been described [26]. Therefore, we co-stimulated $3 \times 10^{4} \mathrm{hRPE}$ cells with IFN- $\gamma$ and IL-1 $\beta$ or TNF $\alpha$, respectively, in 96-well plates. This co-stimulation leads to a slight increase of IDO1 activity, as observed by the formation of kynurenine in the cell-culture supernatants obtained after stimulation with 60-500 U/ml IFN- $\gamma$ (Fig. 2a). Therefore, we expected a synergistic effect of all three cytokines. However, unexpectedly, the co-stimulation of IFN- $\gamma$, IL- $1 \beta$, and TNF $\alpha$ resulted in a significant reduction of the kynurenine production at IFN- $\gamma$ concentrations above $125 \mathrm{U} / \mathrm{ml}$. Such an inhibition of IDO1 activity could be the result of the induction of iNOS. To find out whether iNOS is involved in the inhibition of IDO1 activity, we repeated the experiment in the presence of $\mathrm{N}^{\mathrm{G}}$-monomethyl-L-arginine ( $\mathrm{N}^{\mathrm{G}} \mathrm{MMA}$ ), a competitive inhibitor that reduces the iNOS-mediated conversion of arginine 


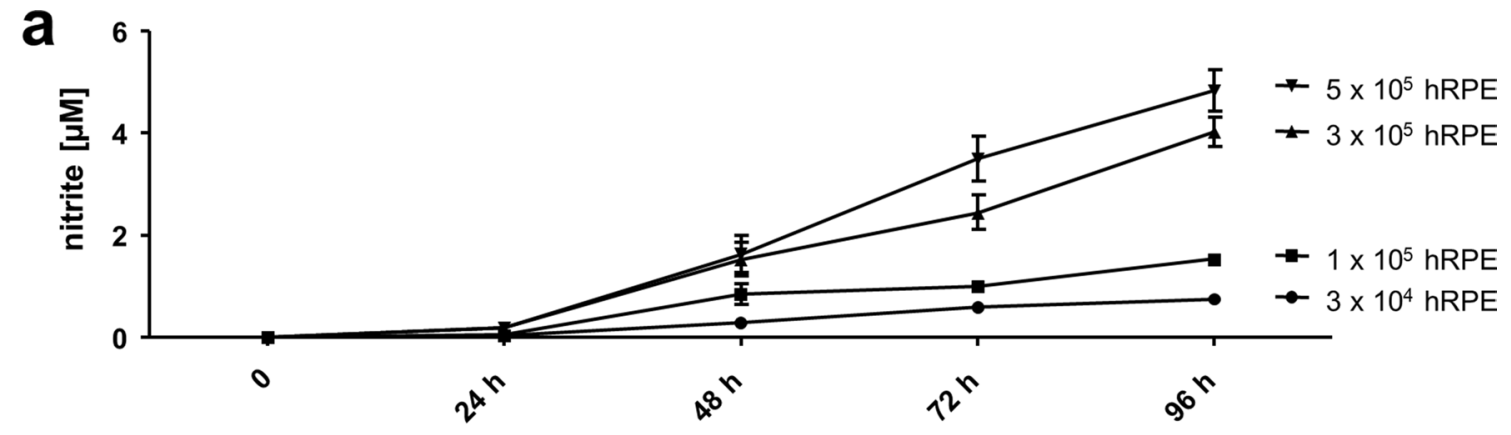

b

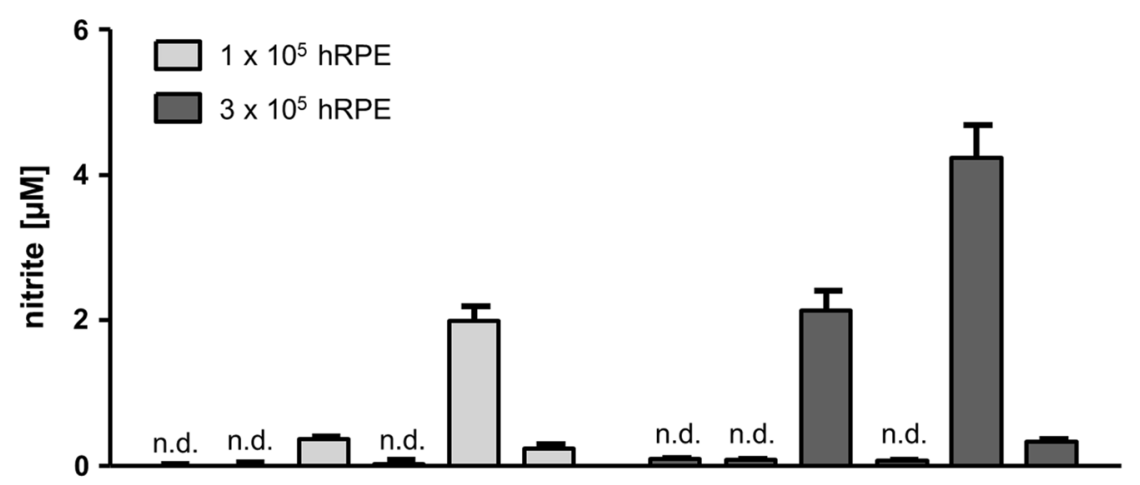

\begin{tabular}{rr|r|c|c|c|c|c|c|c|c|c|c|c|c|}
$\mathrm{IFN}-\mathrm{Y}$ & {$[500 \mathrm{U} / \mathrm{ml}]$} & - & + & + & + & + & + & - & + & + & + & + & + \\
\hline $\mathrm{IL}-1 \beta$ & {$[100 \mathrm{U} / \mathrm{ml}]$} & - & - & + & - & + & + & - & - & + & - & + & + \\
\hline $\mathrm{TNFa}[100 \mathrm{U} / \mathrm{ml}]$ & - & - & - & + & + & + & - & - & - & + & + & + \\
\hline $\mathrm{NGMMA}^{\mathrm{N}}[100 \mathrm{\mu g} / \mathrm{ml}]$ & - & - & - & - & - & + & - & - & - & - & - & + \\
\hline
\end{tabular}

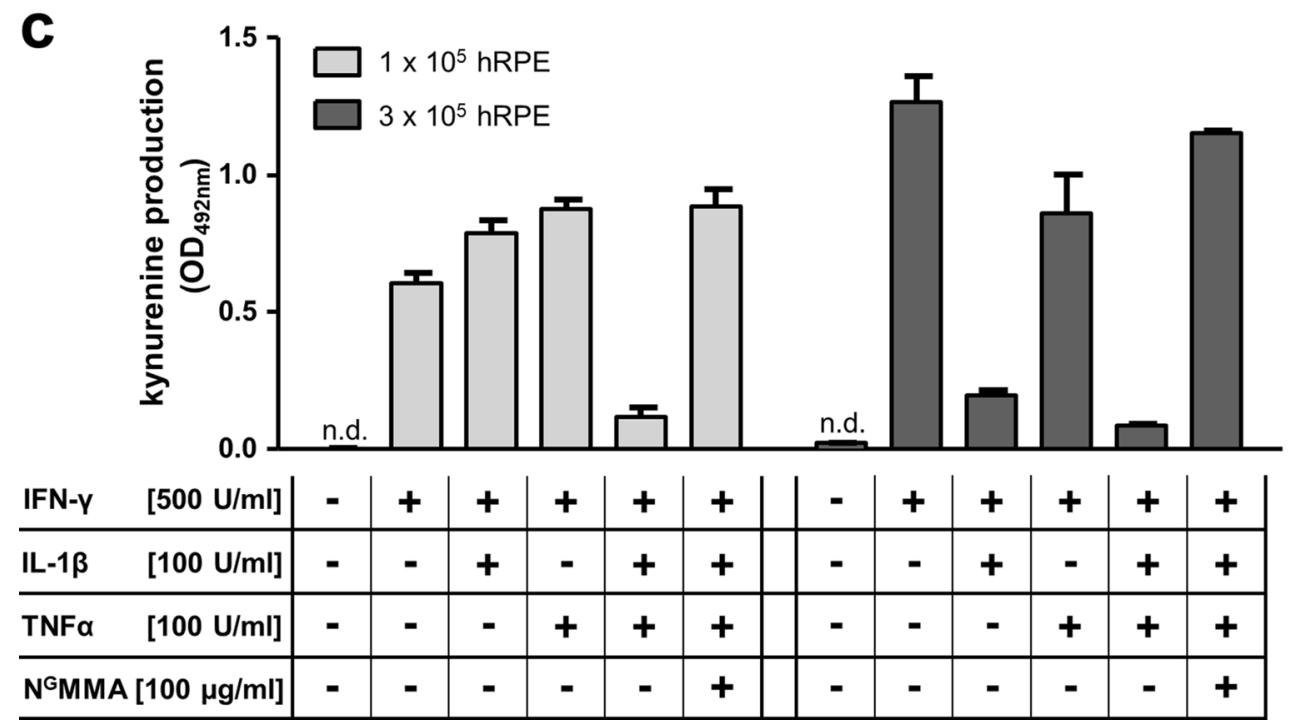

to nitric oxide (NO). $\mathrm{N}^{\mathrm{G}}$ MMA had no effect on IFN- $\gamma$ induced IDO1 activity (Fig. 2b). In addition, the presence of $\mathrm{N}^{\mathrm{G}} \mathrm{MMA}$ did not influence IDO1, which was co-stimulated by IFN- $\gamma$ and IL- $1 \beta$ or IFN- $\gamma$ and TNF $\alpha$ (Fig. $2 b$ ). Interestingly, $\mathrm{N}^{\mathrm{G}} \mathrm{MMA}$ supplementation restored IDO1 activity after co-stimulation with all three cytokines (Fig. 2b). Therefore, it seems probable that the co-stimulation of hRPE cells with IFN- $\gamma$, IL- $1 \beta$, and TNF $\alpha$ indeed induced iNOS in hRPE cells, which was inhibited by $\mathrm{N}^{\mathrm{G}} \mathrm{MMA}$. Furthermore, NO, the product of iNOS activity must have been the causing agent for the IDO1 inhibition. 
4 Fig. 3 Optimized NO production and impact of high NO levels on IDO1. a $3 \times 10^{4}, 1 \times 10^{5}, 3 \times 10^{5}$, or $5 \times 10^{5} \mathrm{hRPE}$ cells were stimulated in 24-well plates with human IFN- $\gamma(500 \mathrm{U} / \mathrm{ml}), \mathrm{IL}-1 \beta(100 \mathrm{U} /$ $\mathrm{ml})$, and TNF $\alpha(100 \mathrm{U} / \mathrm{ml})$ for $0-96 \mathrm{~h}$. From each probe, $100 \mu \mathrm{l}$ cell-culture supernatant was added to $100 \mu \mathrm{l}$ Griess Reagent $(0.1 \%$ $N$-(1-napthyl)ethylendiamin [in aqua dest. plus $2.5 \%$ sulfanilamid (in $15 \% \mathrm{HCl}$ ) in equal parts] and the nitrite was quantified by measuring the optical density at $540 \mathrm{~nm}$. b $1 \times 10^{5}$ or $3 \times 10^{5} \mathrm{hRPE}$ cells were stimulated in the presence $(+)$ or absence $(-)$ of IFN- $\gamma(500 \mathrm{U} /$ $\mathrm{mL})$, IL-1 $\beta(100 \mathrm{U} / \mathrm{ml}), \mathrm{TNF} \alpha(100 \mathrm{U} / \mathrm{ml})$, or $\mathrm{N}^{\mathrm{G}} \mathrm{MMA}(100 \mu \mathrm{g} / \mathrm{ml})$. After $72 \mathrm{~h}, 100 \mu \mathrm{l}$ cell-culture supernatant was added to $100 \mu \mathrm{l}$ Griess Reagent $(0.1 \% N$-(1-Napthyl)ethylendiamin [in aqua dest. plus $2.5 \%$ Sulfanilamid (in $15 \% \mathrm{HCl}$ ) in equal parts] and the nitrite was quantified by measuring the optical density at $540 \mathrm{~nm}$. c $1 \times 10^{5}$ or $3 \times 10^{5}$ hRPE cells were stimulated in the presence $(+)$ or absence $(-)$ of IFN- $\gamma(500 \mathrm{U} / \mathrm{mL}), \mathrm{IL}-1 \beta(100 \mathrm{U} / \mathrm{ml}), \mathrm{TNF} \alpha(100 \mathrm{U} / \mathrm{ml})$, or $\mathrm{N}^{\mathrm{G}} \mathrm{MMA}$ $(100 \mu \mathrm{g} / \mathrm{ml})$. After $72 \mathrm{~h}$, the cell-culture supernatants were harvested and the kynurenine content was determined by the use of Ehrlich's reagent. Data are given as mean \pm SEM of two experiments, each performed in triplicate

Nevertheless, we wanted to confirm that indeed, iNOS and not the other NO-synthases (endothelial or neuronal NOS, eNOS, and nNOS, respectively) were responsible for the formation of NO. Real-time PCR studies revealed a highly significant increase of iNOS in hRPE cells after co-stimulation with IFN- $\gamma$, IL- $1 \beta$, and TNF $\alpha$ (Fig. 2c), which was not affected by the addition of the competitive inhibitor $\mathrm{N}^{\mathrm{G}} \mathrm{MMA}$ as expected (Fig. 2c). Due to the low mRNA expression of the other NO-synthases, we assume that nNOS and eNOS do not play a major role in the inhibition of IDO1 in hRPE cells (Fig. 2c). In sum, the co-stimulation of IFN- $\gamma$, IL- $1 \beta$, and TNF $\alpha$ results in the induction of NO producing iNOS, which inhibits the IDO1-mediated degradation of tryptophan to kynurenine.

Next, we verified nitric oxide production indirect by detection of nitrite in the supernatant of IFN- $\gamma$, IL-1 $\beta$, and TNF $\alpha$ co-stimulated hRPE cells by the use of Griess Reagent. We could not detect significant amounts of NO in $3 \times 10^{4}$ co-stimulated hRPE cells in 96-well plates (data not shown). However, higher levels of $\mathrm{NO}$ accumulated in cell-culture supernatants of $1 \times 10^{5}$ up to $5 \times 10^{5}$ co-stimulated hRPE cells in 24-well plates over time. Therefore, the amount of NO is dependent on the cell number used in the experiments (Fig. 3a).

We continued with the 24-well-plate experimental setting and analyzed the NO production in $1 \times 10^{5}$ differently stimulated hRPE cells. IFN- $\gamma$ stimulation did not exceed the NO production of the negative control, whereas a combinatorial treatment of hRPE cells with IFN-y and IL- $1 \beta$ leads to iNOS activity (Fig. 3b). In contrast, no NO was detectable after the combinatorial treatment with IFN-y and TNF- $\alpha$ (Fig. 3b). Interestingly, as expected, the stimulation with all three cytokines resulted in an intense formation of NO and the addition of $\mathrm{N}^{\mathrm{G}} \mathrm{MMA}$ prevented the generation of NO
(Fig. 3b). All observations were enhanced by the usage of $1 \times 10^{5}$ hRPE cells (Fig. 3b).

Since not only the co-stimulation with all three cytokines resulted in a significant NO production in the modified experimental system, but also the combination of IFN- $\gamma$ and IL- $1 \beta$ alone, we were interested in whether the latter stimulation had an influence on IDO activity. Although IDO activity has not been influenced by IFN- $\gamma$ and IL- $1 \beta$ stimulation in $3 \times 10^{4} \mathrm{hRPE}$ cells (Fig. 2a) and in $1 \times 10^{5} \mathrm{hRPE}$ cells (Fig. 3c), IDO activity was clearly inhibited by IFN- $\gamma$ and IL- $1 \beta$-induced NO production in $3 \times 10^{5}$ stimulated hRPE cells (Fig. 3c). These results indicate that a sufficient NO concentration is indispensable for a significant inhibition of IDO activity.

\section{Influence of iNOS activity on indoleamine 2,3-dioxygenase-1 in human retinal pigment epithelial cells}

Next, we elucidated whether iNOS activity inhibits IDO1 on transcriptional, translational, or post-translational level. In real-time analyses, IDO1 mRNA induction was detected upon IFN- $\gamma$ stimulation (Fig. 4a). Neither combinatorial stimulation with IFN- $\gamma / \mathrm{IL}-1 \beta$, nor IFN- $\gamma / \mathrm{TNF} \alpha$, nor IFN- $\gamma /$ IL- $1 \beta /$ TNF $\alpha$ lead to a reduced IDO1 mRNA expression (Fig. 4a).

Western blot analyses revealed no reduction of IDO1 protein levels upon IFN- $\gamma / \mathrm{IL}-1 \beta$, IFN- $\gamma / \mathrm{TNF} \alpha$ or IFN- $\gamma / \mathrm{IL}-1 \beta /$ TNF $\alpha$ stimulation (Fig. 4b). As expected, $N^{G}$ MMA had no effect on IDO1 protein levels as well.

Finally, we wanted to elucidate whether iNOS-generated NO is sufficient to have a potential role during EBE. Since NO inhibits the IDO1-mediated kynurenine production, we wanted to find out whether IDO1-mediated antibacterial effects are also abolished. Therefore, IFN- $\gamma$ or IFN- $\gamma$ / IL-1 $\beta / T N F \alpha$ pre-stimulated hRPE cells were infected with $S$. aureus and the bacterial growth was determined after additional $16 \mathrm{~h}$ by measurement of the optical density. Bacterial growth was inhibited in IFN- $\gamma$ pre-stimulated cells as before (Fig. 3c). Interestingly, the co-stimulation with IFN- $\gamma$, IL- $1 \beta$, and TNF $\alpha$ impeded the IDO1 antibacterial activity, which allowed an unhindered S. aureus growth (Fig. 4c). The presence of $\mathrm{N}^{\mathrm{G}}$ MMA during the stimulation period sufficiently neutralized this effect (Fig. 4c).

\section{Discussion}

The eye is an immune-privileged site. This privilege is established by the RPE. The RPE cells play a crucial role in retinal physiology, in the induction of immunosuppression and in antimicrobial defense [4]. Eye infections cause harm to vision. The work of several research groups focusses 
especially on CMV and T. gondii-caused infections, since both pathogens induce numerous eye infections.

For example, Noguereia et al. described barrier dysfunction of human RPE cells due to altered tight junctions after in vitro infection with $T$. gondii $\mathrm{RH}$ strain tachyzoites [31]. Delaire et al. found out that IFN- $\gamma$ activated native Lewis rat RPE cells are able to inhibit the growth of $T$. gondii $(\mathrm{RH}$ strain) tachyzoites [5]. Furthermore, stimulation with TNF $\alpha$ alone inhibited $T$. gondii growth slightly. A combined treatment of native Lewis rat RPE cells with IFN- $\gamma$ and TNF $\alpha$ resulted in a synergistic effect. Further data from this group suggest that iNOS was not involved in the toxoplasmostatic effect [31]. In accordance with data from Delaire et al., Nagineni et al. found that primary human RPE lines stimulated with IFN- $\alpha$, IFN- $\beta$, IFN- $\gamma$, and TNF $\alpha$ are able to inhibit $T$. gondii growth (RH strain), while IFN- $\gamma$ was the most efficient cytokine [5, 6]. Interestingly, both groups hold the induction of the tryptophan-degrading enzyme IDO1 responsible for the antiparasitic effect observed in IFN- $\gamma$ stimulated human RPE cells [5, 6]. In detail, they detected IDO1 mRNA and protein in IFN- $\gamma$-stimulated RPE cells. Tryptophan supplementation dramatically reduced the antiparasitic effect of IFN- $\gamma$-stimulated RPE cells against $T$. gondii. Type I $T$. gondii, such as the RH strain, are highly virulent in mice. However, the majority of $T$. gondii isolates are type II strains, whereas type I strains are rarely isolated in humans [30]. Chronically infected patients, especially those with toxoplasmic chorioretinitis, are most frequently affected by type II strains [30]. Due to this reason, we used the $T$. gondii type II strain ME49 in our experimental setup. We confirmed the production of IDO1 mRNA and protein in IFN- $\gamma$ stimulated hRPE ARPE19 cells. Since these cells express IDO1 as well as iNOS simultaneously after IFN$\gamma$, IL- $1 \beta$, and TNF $\alpha$ stimulation, we conclude that in this respect, the ARPE19 cell line used in this study is comparable to native hRPE cells $[6,7]$. Beyond that, we could show that there was no noteworthy amount of IDO2 mRNA in IFN- $\gamma$-stimulated hRPE cells. In addition, we were able to prove IDO1 enzyme activity, since we measured an accumulation of kynurenine in the cell-culture supernatant of IFN$\gamma$-stimulated hRPE cells. Furthermore, we could ascribe the IFN- $\gamma$-induced antiparasitic effect to IDO1, since we found that tryptophan supplementation at the timepoint of infection results in a nearly complete recovery of $T$. gondii ME49 tachyzoite growth. However, we observed that there was no full recovery of $T$. gondii growth by supplemental tryptophan in hRPE cells pre-treated with high doses of IFN- $\gamma$. This might be a hint for the presence of toxic amounts of kynurenine or kynurenine-derived metabolites that affect the parasites, but not $S$. aureus or host cells [32].

Staphylococcus aureus is the most frequent causative agent in patients with endogenous endophthalmitis (EBE). We revealed that IDO1 activity inhibits $S$. aureus growth in human brain microvascular endothelial cells [33]. Here, we found that IFN- $\gamma$-activated hRPE cells restrict the growth of $S$. aureus and that tryptophan supplementation abrogates this antibacterial effect. These data indicate that hRPE cells are antimicrobial effector cells that might influence EBE. The cleavage of tryptophan by IDO1 is critically dependent on the availability of oxygen [34]. Under physiologic conditions, the RPE has an oxygen saturation of approximately $8 \%$ $\mathrm{O}_{2}$ [35]. Therefore, we incubated hRPE cells under normoxic $\left(20 \% \mathrm{O}_{2}\right)$, physiologic $\left(8 \% \mathrm{O}_{2}\right)$ and hypoxic $\left(1 \% \mathrm{O}_{2}\right)$ conditions. We found that IDO1 activity was strongly reduced during cultivation under the hypoxic oxygen concentration (1\% $\mathrm{O}_{2}$ ), while IDO1 activity was only marginally influenced in hRPE cells cultivated under physiologic oxygen levels ( $8 \%$ $\left.\mathrm{O}_{2}\right)$ in comparison with normoxia $\left(20 \% \mathrm{O}_{2}\right)$. This means that IDO1 is active at physiologic oxygen concentration in the hRPE cell monolayer in vivo, but might be affected under pathophysiological conditions during inflammation.

In previous experiments with human glioblastoma cells and alveolar epithelial cells, we found that TNF $\alpha$ and IL-1 $\beta$, respectively, did not induce IDO1 directly, but required IFN- $\gamma$ to synergistically induce IDO1 $[26,36]$. Co-stimulation of hRPE cells with IFN- $\gamma$ and TNF $\alpha$ or IL- $1 \beta$ increased IDO1 activity significantly. However, a combined stimulation with IFN- $\gamma$, IL- $1 \beta$, and TNF $\alpha$ resulted in a strong inhibition of IFN- $\gamma$-induced IDO1 activity, especially at higher IFN- $\gamma$ doses. Since nitric oxide is capable of inhibiting IDO1 activity [37], we assumed that iNOS induction in hRPE cells by this cytokine cocktail might be responsible for the observed IDO1 inhibition.

Earlier publications described iNOS transcription, expression, and activity in human native RPE cells as well as in the RPE cell line ARPE19 [7, 17, 22]. In this context, iNOS activity was induced by stimulation with different cytokines (for example, with IFN- $\gamma$, TNF $\alpha$, and/or IL-1 $\beta$ ). In addition to the cytokine-dependent iNOS activation, also nonimmune iNOS activation has been observed in hRPE cells. Here, iNOS was induced by all-trans retinal, an intermediate in the vision cycle, or by cultivation under high-glucose conditions [22, 38]. In addition, iNOS is detectable in RPE cells from other species, including pigs, cows, mice, and rats [18, 39]. Interestingly, iNOS has potent antimicrobial activities and inhibits the spread of murine CMV, but overexpression of iNOS can also damage RPE cells, change neovascularization in ischemic retinopathy, and is associated with the severity of diabetic retinopathy in mice and humans [16, 19, 40].

Here, we found that hRPE cells do not express iNOS activity after IFN- $\gamma$ stimulation, but after co-stimulation of hRPE cells with IFN- $\gamma / \mathrm{IL}-1 \beta$ as well as IFN- $\gamma / \mathrm{TNF}-\alpha / \mathrm{IL}-1 \beta$. The magnitude of nitric oxide production is dependent on several factors, including cell number, cytokine concentration, and cultivation time. iNOS activity in hRPE cells 
a

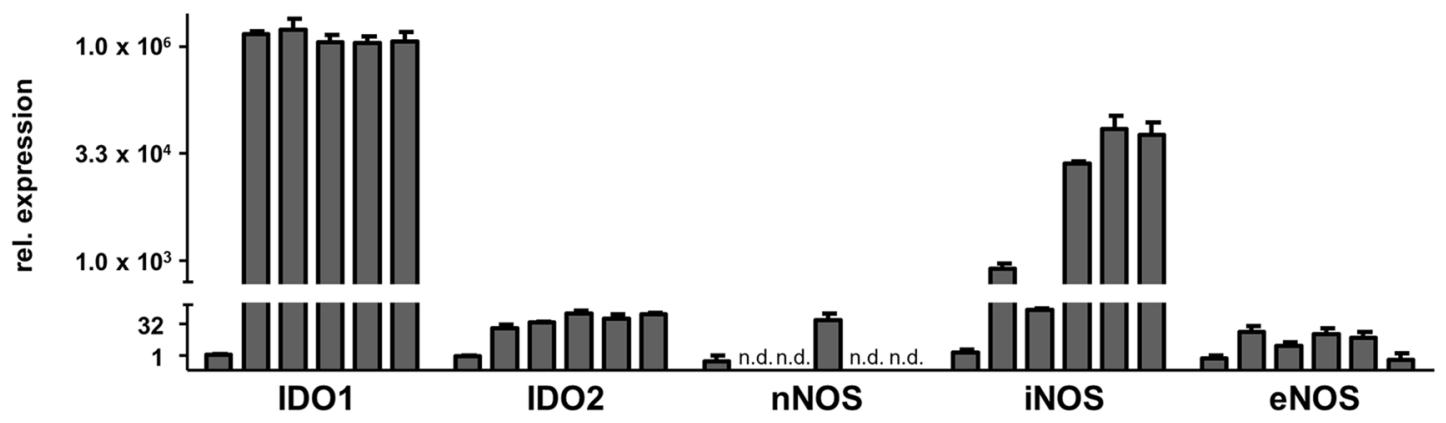

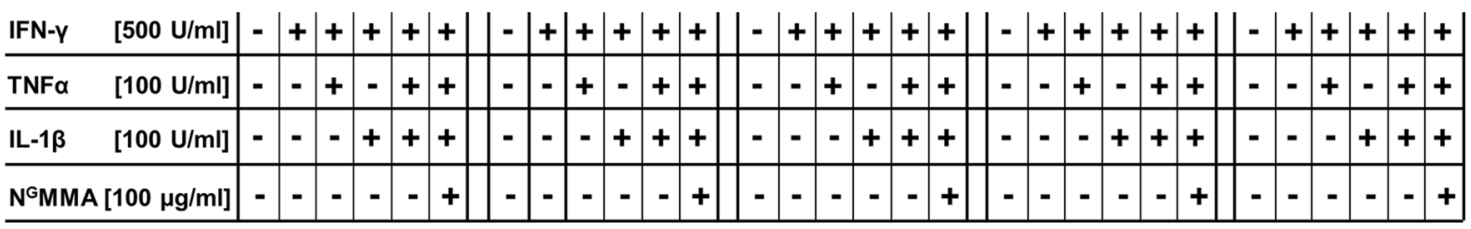

b

\begin{tabular}{|c|c|c|c|c|c|c|c|c|c|c|}
\hline & & & & & & & & & & \\
\hline & ID01 & & - & - & $=$ & $=$ & $=$ & - & & \\
\hline & -actin & & & & & & & & & \\
\hline IFN-Y & {$[500 \mathrm{U} / \mathrm{ml}]$} & - & + & + & + & + & + & + & - & + \\
\hline TNFa & {$[100 \mathrm{U} / \mathrm{ml}]$} & - & - & - & + & - & + & + & - & - \\
\hline IL-1 $\beta$ & {$[100 \mathrm{U} / \mathrm{ml}]$} & - & - & + & - & - & + & + & - & - \\
\hline $\mathrm{N}^{\mathrm{G}} \mathrm{MM}$ & {$[100 \mu \mathrm{g} / \mathrm{ml}]$} & - & - & - & - & + & - & + & - & - \\
\hline
\end{tabular}

C

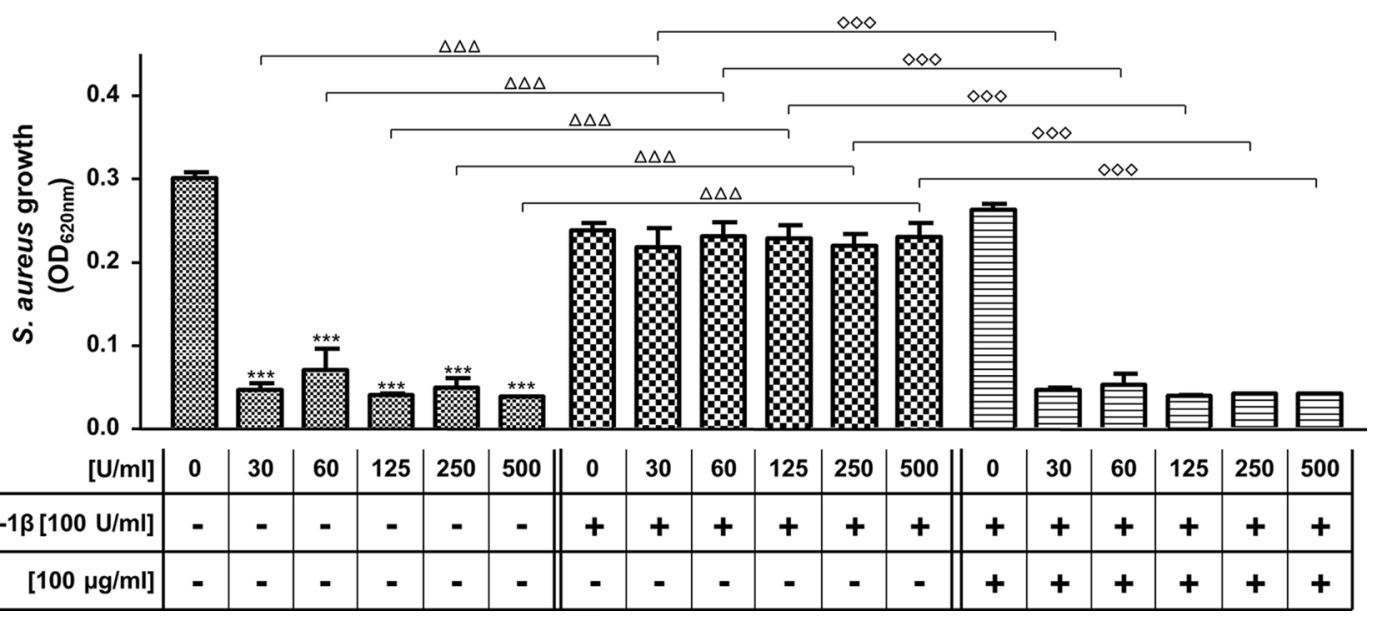

Fig. 4 Influence of iNOS activity on indoleamine 2,3-dioxygenase-1 in human retinal pigment epithelial cells. a Relative expression of IDO1, IDO2, neuronal (nNOS), inducible (iNOS), and endothelial nitric oxide synthase (eNOS) $24 \mathrm{~h}$ poststimulation as determined by real-time PCR. hRPE cells were untreated or stimulated with combinations of IFN- $\gamma(500 \mathrm{U} / \mathrm{ml}), \mathrm{IL}-1 \beta(100 \mathrm{U} / \mathrm{ml}), \mathrm{TNF} \alpha(100 \mathrm{U} / \mathrm{ml})$, and $\mathrm{N}^{\mathrm{G}} \mathrm{MMA}$ $(100 \mu \mathrm{g} / \mathrm{ml})$ as indicated. b Western blot analysis of IDO1 and $\beta$-actin protein expression by hRPE cells in the presence $(+)$ or absence $(-)$ of IFN- $\gamma(500 \mathrm{U} / \mathrm{ml})$, IL-1 $\beta(100 \mathrm{U} / \mathrm{ml})$, or TNF $\alpha(100 \mathrm{U} / \mathrm{ml})$. Unstimulated and IFN- $\gamma(500 \mathrm{U} / \mathrm{ml})$ stimulated human glioblastoma cell lysates were used as controls, respectively. c $3 \times 10^{4} \mathrm{hRPE}$ cells pre-stimulated with IFN- $\gamma$ and/or IL-1 $\beta$ and TNF $\alpha(100 \mathrm{U} / \mathrm{ml}$ each) for $72 \mathrm{~h}$ were infected with Staphylococcus aureus (10-100 cfu/well). The bacterial growth was detected by measurement of the optical density at $620 \mathrm{~nm}$ after $16 \mathrm{~h}$. Data are given as mean \pm SEM of two (a), one (b) or three (c) experiments, each performed in triplicate. Significant inhibition of bacterial growth in IFN- $\gamma$ stimulated hRPE cells is marked with asterisks $(* p \leq 0.05, * * p \leq 0.001$, and $* * * p \leq 0.0001)$. Significant inhibition of the antibacterial effect by co-stimulation with IL- $1 \beta$ and TNF $\alpha$ is marked with triangles. Significant recovery of the antibacterial effector mechanism via $\mathrm{N}^{\mathrm{G}} \mathrm{MMA}$ supplementation is marked with diamonds. The unpaired, two-tailed student's $t$ test was used 
could be blocked by addition of the NOS antagonist $N^{\mathrm{G}}$ monomethyl-L-arginine ( $\left.{ }^{\mathrm{G}} \mathrm{MMA}\right)$. We confirmed via realtime PCR analyses that the inducible form of NO-synthases (iNOS, also known as NOS2) was indeed upregulated after co-stimulation with IFN- $\gamma$, TNF $\alpha$, and IL- $1 \beta$, whereas no noteworthy mRNA amounts of endothelial (eNOS also known as NOS 3) or neuronal NO-synthases (nNOS, also known as NOS 1) were detectable. IDO1 as well as iNOS are described as potent antimicrobial effector mechanisms [41]. However, we could not find a synergistic antimicrobial effect of both IFN- $\gamma$-induced effector mechanisms directed against $S$. aureus or T. gondii. Instead, iNOS activity generated sufficient NO concentrations that were capable to inhibit IDO1 activity, which could be reversed by iNOS inhibition via $\mathrm{N}^{\mathrm{G}} \mathrm{MMA}$ administration. Several possibilities such as altered transcription, translation, or post-translational modifications could account for this NO-mediated IDO1 inhibition. Relative IDO1 mRNA expression levels, as detected by real-time PCR analyses, were not influenced by the presence of NO; hence, a reduced IDO1 transcription cannot be responsible for the low IDO1 activity. Furthermore, IDO1 protein levels are unaffected in different single or combinatorial cytokine stimulation assays as shown by western blot analyses. Due to that, we expect that NO does not influence IDO1 on a translational level in hRPE. In conclusion, we assume that NO directly interacts with the IDO1 protein. Such an interaction was published by Thomas et al. before [42]. They described the direct interaction of NO with the heme group of the IDO1 molecule in a cell-free environment. To elucidate the IDO1-NO interaction in hRPE cells in more detail, it would be necessary to purify IDO1 protein for biochemical studies using a NO donor.

In a previous publication, we described a comparable direct effect of iNOS on IDO enzyme activity using lysates of activated RT4 cells (human uroepithelial carcinoma cell line) and a chemical NO donor [37]. In addition, we have previously described that iNOS activation causes an enhanced proteasomal degradation of IDO1 protein in RT4 cells [37]. A comparable iNOS-dependent loss of IDO protein expression in hepatocytes was described by Bando et al. very recently [43]. However, it is not very likely that the proteasomal degradation mechanism takes place in hRPE cells, since we did not find a reduced IDO protein expression in IFN- $\gamma$, TNF $\alpha$, and IL- $1 \beta$ single or co-stimulated hRPE cells. In addition, there was no reduction of IDO1 mRNA detectable in iNOS-positive cells.

Here, we show that iNOS-mediated inhibition of IDO1 in hRPE cells abrogates also subsequent antiparasitic and antibacterial effects. In functional analyses, we found that the iNOS inhibitor $\mathrm{N}^{\mathrm{G}} \mathrm{MMA}$ restored the capacity of hRPE cells to inhibit $S$. aureus and $T$. gondii growth. This opens the question which function the iNOS-mediated IDO1 inhibition might have in human cells. In general, iNOS production by human cells in vitro is not intense and in many cases undetectable. In contrast, murine cells often produce high amounts of nitric oxide, which are sufficient to inhibit the growth of pathogens, for example, $T$. gondii [44]. In addition, other IFN- $\gamma$-induced antimicrobial effector mechanisms, such as immunity-related guanosine triphosphatases and guanylate binding proteins, act in concert with iNOS to inhibit $T$. gondii growth in murine cells. In contrast, in human cells, IDO1 is an important antimicrobial protein. The intensity of IDO induction directly correlates with the amount of IFN- $\gamma$ used for stimulation. Since IDO is the ratelimiting enzyme in the kynurenine pathway, an excessive IDO1 induction results in tryptophan starvation, which is an unfavorable situation for the host cells. Furthermore, the production of toxic metabolites along the kynurenine pathway such as kynurenine and 3OH-kynurenine might be harmful for immune and tissue cells $[45,46]$ or induce a plethora of effects via aryl hydrocarbon receptor signaling [47]. Therefore, control of IDO1 activity by NO might be beneficial to reduce detrimental IDO1-mediated cell damage.

Acknowledgements This work was funded by the Manchot Graduate School Molecules of Infections III (to W. D.). C-MU is a scholarship holder as part of the Manchot Graduate School Molecules of Infections III.

\section{Compliance with ethical standards}

Conflict of interest The authors declare that they have no conflict of interest.

Research involving human and/or animal participants This article does not contain any studies with human participants or animals performed by any of the authors.

Open Access This article is distributed under the terms of the Creative Commons Attribution 4.0 International License (http://creativeco mmons.org/licenses/by/4.0/), which permits unrestricted use, distribution, and reproduction in any medium, provided you give appropriate credit to the original author(s) and the source, provide a link to the Creative Commons license, and indicate if changes were made.

\section{References}

1. Durand ML (2013) Endophthalmitis. Clin Microbiol Infect 19:227-234. https://doi.org/10.1111/1469-0691.12118

2. Mochizuki M, Sugita S, Kamoi K (2013) Immunological homeostasis of the eye. Prog Retin Eye Res 33:10-27. https://doi. org/10.1016/j.preteyeres.2012.10.002

3. Denkers EY, Gazzinelli RT (1998) Regulation and function of T-cell-mediated immunity during Toxoplasma gondii infection. Clin Microbiol Rev 11:569-588

4. Stein-Streilein J (2008) Immune regulation and the eye. Trends Immunol 29:548-554. https://doi.org/10.1016/j.it.2008.08.002

5. Delair E, Creuzet C, Dupouy-Camet J, Roisin MP (2009) In vitro effect of TNF-alpha and IFN-gamma in retinal cell infection with 
Toxoplasma gondii. Invest Ophthalmol Vis Sci 50:1754-1760. https://doi.org/10.1167/iovs.07-1376

6. Nagineni CN, Pardhasaradhi K, Martins MC, Detrick B, Hooks JJ (1996) Mechanisms of interferon-induced inhibition of Toxoplasma gondii replication in human retinal pigment epithelial cells. Infect Immun 64:4188-4196

7. Bodaghi B, Goureau O, Zipeto D, Laurent L, Virelizier JL et al (1999) Role of IFN-gamma-induced indoleamine 2,3 dioxygenase and inducible nitric oxide synthase in the replication of human cytomegalovirus in retinal pigment epithelial cells. J Immunol 162:957-964

8. Zimmermann A, Hauka S, Maywald M, Le VT, Schmidt SK, Däubener W et al (2014) Checks and balances between human cytomegalovirus replication and indoleamine-2,3-dioxygenase. J Gen Virol 95:659-670. https://doi.org/10.1099/vir.0.061994-0

9. Jackson TL, Paraskevopoulos T, Georgalas I (2014) Systematic review of 342 cases of endogenous bacterial endophthalmitis. Surv Ophthalmol 59:627-635. https://doi.org/10.1016/j.survo phthal.2014.06.002

10. Coburn PS, Wiskur BJ, Astley RA, Callegan MC (2015) Bloodretinal barrier compromise and endogenous Staphylococcus aureus endophthalmitis. Invest Ophthalmol Vis Sci 56:73037311. https://doi.org/10.1167/iovs.15-17488

11. Cunha-Vaz J, Bernardes R, Lobo C (2011) Blood-retinal barrier. Eur J Ophthalmol Suppl 6:3-9. https://doi.org/10.5301/ EJO.2010.6049

12. Holtkamp GM, Kijlstra A, Peek R, de Vos AF (2001) Retinal pigment epithelium-immune system interactions: cytokine production and cytokine-induced changes. Prog Retin Eye Res 20:29-48

13. Huemer HP, Larcher C, Kirchebner W, Klingenschmid J, Göttinger W et al (1996) Susceptibility of human retinal pigment epithelial cells to different viruses. Graefes Arch Clin Exp Ophthalmol 234:177-185

14. Sparrow JR, Nathan C, Vodovotz Y (1994) Cytokine regulation of nitric oxide synthase in mouse retinal pigment epithelial cells in culture. Exp Eye Res 59:129-139

15. Koga T, Zhang WY, Gotoh T, Oyadomari S, Tanihara $\mathrm{H}$ et al (2003) Induction of citrulline-nitric oxide (NO) cycle enzymes and NO production in immunostimulated rat RPE-J cells. Exp Eye Res 76:15-21

16. Zhang M, Zhou J, Marshall B, Xin H, Atherton SS (2007) Lack of iNOS facilitates MCMV spread in the retina. Invest Ophthalmol Vis Sci 48:285-292

17. Goureau O, Hicks D, Courtois Y (1994) Human retinal pigmented epithelial cells produce nitric oxide in response to cytokines. Biochem Biophys Res Commun 198:120-126

18. Faure V, Courtois Y, Goureau O (1999) Differential regulation of nitric oxide synthase-II mRNA by growth factors in rat, bovine, and human retinal pigmented epithelial cells. Ocul Immunol Inflamm 7:27-34

19. Sennlaub F, Courtois Y, Goureau O (2002) Inducible nitric oxide synthase mediates retinal apoptosis in ischemic proliferative retinopathy. J Neurosci 22:3987-3993

20. Bhutto IA, Baba T, Merges C, McLeod DS, Lutty GA (2010) Low nitric oxide synthases (NOSs) in eyes with age-related macular degeneration (AMD). Exp Eye Res 90:155-167. https://doi. org/10.1016/j.exer.2009.10.004

21. Neufeld AH, Sawada A, Becker B (1999) Inhibition of nitric-oxide synthase 2 by aminoguanidine provides neuroprotection of retinal ganglion cells in a rat model of chronic glaucoma. Proc Natl Acad Sci USA 96:9944-9948

22. Zhang X, Fu Y, Xu X, Li M, Du L et al (2014) PERK pathway are involved in NO-induced apoptosis in endothelial cells cocultured with RPE under high glucose conditions. Nitric Oxide 40:10-16. https://doi.org/10.1016/j.niox.2014.05.001
23. Coburn PS, Wiskur BJ, Miller FC, LaGrow AL, Astley RA et al (2016) Bloodstream-to-eye infections are facilitated by outer blood-retinal barrier dysfunction. PLoS One 11:e0154560. https ://doi.org/10.1371/journal.pone.0154560

24. Irschick EU, Sgonc R, Böck G, Wolf H, Fuchs D et al (2004) Retinal pigment epithelial phagocytosis and metabolism differ from those of macrophages. Ophthalmic Res 36:200-210

25. Osusky R, Dorio RJ, Arora YK, Ryan SJ, Walker SM (1997) MHC class II positive retinal pigment epithelial (RPE) cells can function as antigen-presenting cells for microbial superantigen. Ocul Immunol Inflamm 5:43-50

26. Heseler K, Spekker K, Schmidt SK, MacKenzie CR, Däubener W (2008) Antimicrobial and immunoregulatory effects mediated by human lung cells: role of IFN-gamma-induced tryptophan degradation. FEMS Immunol Med Microbiol 52:273-281

27. Däubener W, Wanagat N, Pilz K, Seghrouchni S, Fischer HG et al (1994) A new, simple bioassay for human IFN-gamma. J Immunol Methods 168:39-47

28. Ding AH, Nathan CF, Stuehr DJ (1988) Release of reactive nitrogen intermediates and reactive oxygen intermediates from mouse peritoneal macrophages. Comparison of activating cytokines and evidence for independent production. J Immunol 141:2407-2412

29. Pfefferkorn ER, Pfefferkorn LC (1977) Specific labeling of intracellular toxoplasma gondii with uracil. J. Protozool 24:449-453

30. Schlüter D, Däubener W, Schares G, Groß U, Pleyer U et al (2014) Animals are key to human toxoplasmosis. Int J Med Microbiol 304:917-929. https://doi.org/10.1016/j.ijmm.2014.09.002

31. Nogueira AR, Leve F, Morgado-Diaz J, Tedesco RC, Pereira MC (2016) Effect of Toxoplasma gondii infection on the junctional complex of retinal pigment epithelial cells. Parasitol 143:568 575. https://doi.org/10.1017/S0031182015001973

32. Eller SK, Däubener W (2015) Role of kynurenine pathway in infection. In: Mittal S (ed) Targeting the broadly pathogenic kynurenine pathway. Springer, Heidelberg, pp 179-190

33. Schroten H, Spors B, Hucke C, Stins M, Kim KS et al (2001) Potential role of human brain microvascular endothelial cells in the pathogenesis of brain abscess: inhibition of Staphylococcus aureus by activation of indoleamine 2,3-dioxygenase. Neuropediatrics 32:206-210

34. Schmidt SK, Ebel S, Keil E, Woite C, Ernst JF et al (2013) Regulation of IDO activity by oxygen supply: inhibitory effects on antimicrobial and immunoregulatory functions. PLoS One 8:e63301. https://doi.org/10.1371/journal.pone.0063301

35. Wangsa-Wirawan ND, Linsenmeier RA (2003) Retinal oxygen. Arch Ophathalmo 121:547-557

36. Däubener W, Remscheid C, Nockemann S, Pilz K, Seghrouchni S, Mackenzie C, Hadding U (1996) Anti-parasitic effector mechanisms in human brain tumor cells: role of interferon-gamma and tumor necrosis factor-alpha. Eur J Immunol 26:487-492

37. Hucke C, MacKenzie CR, Adjogble KD, Takikawa O, Däubener W (2004) Nitric oxide-mediated regulation of gamma interferoninduced bacteriostasis: inhibition and degradation of human indoleamine 2,3-dioxygenase. Infect Immun 72:2723-2730

38. Zhu X, Wang K, Zhang K, Zhou F, Zhu L (2016) Induction of oxidative and nitrosative stresses in human retinal pigment epithelial cells by all-trans-retinal. Exp Cell Res 348:87-94. https:// doi.org/10.1016/j.yexcr.2016.09.002

39. Klettner A, Hamann T, Schlüter K, Lucius R, Roider J (2014) Retinal pigment epithelium cells alter the pro-inflammatory response of retinal microglia to TLR-3 stimulation. Acta Ophthalmol 92:e621-e629. https://doi.org/10.1111/aos.12472

40. Sharma S, Saxena S, Srivastav K, Shukla RK, Mishra N et al (2015) Nitric oxide and oxidative stress is associated with severity of diabetic retinopathy and retinal structural alterations. Clin Exp Ophthalmol 43:429-436. https://doi.org/10.1111/ceo.12506 
41. Däubener W, Schmidt SK, Heseler K, Spekker KH, MacKenzie CR (2009) Antimicrobial and immunoregulatory effector mechanisms in human endothelial cells. Indoleamine 2,3-dioxygenase versus inducible nitric oxide synthase. Thromb Haemost 102:1110-1116. https://doi.org/10.1160/TH09-04-0250

42. Thomas SR, Terentis AC, Cai H, Takikawa O, Levina A, Lay PA, Freewan M, Stocker RJ (2007) Post-translational regulation of human indoleamine 2,3-dioxygenase activity by nitric oxide. Biol Chem 282:23778-23787

43. Bando H, Lee Y, Sakaguchi N, Pradipta A, Ma JS, Tanaka S, Cai Y, Liu J, Shen J, Nishikawa Y, Sasai M, Yamamoto M (2018) Inducible nitric oxide synthase is a key host factor for toxoplasma GRA15-dependent disruption of the gamma interferon-induced antiparasitic human response. MBio 9:e01738-18. https://doi. org/10.1128/mbio.01738-18

44. Yarovinsky F (2014) Innate immunity to Toxoplasma gondii infection. Nat Rev Immunol 14:109-121. https://doi.org/10.1038/nri35 98
45. Terness P, Bauer TM, Röse L, Dufter C, Watzlik A, Simon H, Opelz G (2002) Inhibition of allogeneic $T$ cell proliferation by indoleamine 2,3-dioxygenase-expressing dendritic cells: mediation of suppression by tryptophan metabolites. J Exp Med 196:447-457

46. Frumento G, Rotondo R, Tonetti M, Damonte G, Benatti U, Ferrara GB (2002) Tryptophan-derived catabolites are responsible for inhibition of $\mathrm{T}$ and natural killer cell proliferation induced by indoleamine 2,3-dioxygenase. J Exp Med 196:459-468

47. Opitz CA, Litzenburger UM, Sahm F, Ott M, Tritschler I, Trump S, Schumacher T, Jestaedt L, Schrenk D, Weller M, Jugold M, Guillemin GJ, Miller CL, Lutz C, Radlwimmer B, Lehmann I, von Deimling A, Wick W, Platten M (2011) An endogenous tumourpromoting ligand of the human aryl hydrocarbon receptor. Nature 478:197-203. https://doi.org/10.1038/nature10491

Publisher's Note Springer Nature remains neutral with regard to jurisdictional claims in published maps and institutional affiliations. 